\title{
Miranda
}

Revue pluridisciplinaire du monde anglophone /

Multidisciplinary peer-reviewed journal on the English-

speaking world

13 | 2016

Thomas Spence and his Legacy: Bicentennial

Perspectives

\section{Beyond the Public and the Private : Thomas Spence and the Current Debate on Common Property}

\section{Matilde Cazzola}

\section{OpenEdition}

\section{Journals}

\section{Electronic version}

URL: http://journals.openedition.org/miranda/9220

DOl: $10.4000 /$ miranda. 9220

ISSN: 2108-6559

\section{Publisher}

Université Toulouse - Jean Jaurès

\section{Electronic reference}

Matilde Cazzola, "Beyond the Public and the Private : Thomas Spence and the Current Debate on Common Property". Miranda [Online], 13 | 2016, Online since 17 November 2016, connection on 16 February 2021. URL: http://journals.openedition.org/miranda/9220 ; DOI: https://doi.org/10.4000/ miranda.9220

This text was automatically generated on 16 February 2021.

\section{c) $(1) \odot$}

Miranda is licensed under a Creative Commons Attribution-NonCommercial-NoDerivatives 4.0 International License. 


\title{
Beyond the Public and the Private: Thomas Spence and the Current Debate on Common Property
}

\author{
Matilde Cazzola
}

\section{The return of the commons}

1 From the perspective of the History of Political Thought, Modernity is the age characterized by the theorization of modern State, which is intimately linked with the defence of private property. In Chapter v "On Property" of Second Treatise of Government (1690), John Locke, the founding father of Liberalism, justified the individual exclusive right to use a natural resource on the basis of the property in one's person and in the labour performed by one's body. Locke also legitimized the right of appropriation and accumulation beyond immediate enjoyment, introducing the use of money (Locke, 285-302). According to Locke, the emergence from the state of nature and the establishment of the State aimed at the protection of private property rights (Locke, $268)$; as a consequence, the revolution and dissolution of government were legitimate when "the Legislators endeavour[ed] to take away, and destroy the Property of the People" (Locke, 412). From a social-historical perspective, Modernity cannot be considered apart from the beginning of capitalistic accumulation via both the enclosure of common lands in Europe and the conquest of the New World. Both these foundational events of modern age entailed a private appropriation of the commonsunenclosed and undivided lands and waters, and natural resources in general, collectively owned and amenable to common rights of pasture, piscary, and turbary. Modernity in this way, both from an intellectual and economic perspective, is indissolubly linked with the privatization of the commons (Federici, 9 ; Linebaugh 2008, 46-47 ; Mattei 2011, 30-35).

2 The commons were the main issue at stake in the political debates and struggles at the dawn of Modernity, especially in England, where the Agricultural Revolution and the 
birth of agrarian capitalism affected them by unparalleled, massive enclosures from the $16^{\text {th }}$ century onwards. These enclosures of land gathered momentum during the English Revolution, exciting the claims of the radical sect of the Diggers (Linebaugh 2008, 85-87). While for nearly two centuries this process took place mainly through informal agreements, starting from the Inclosure Act 1773 enclosure by Acts of Parliament became the norm in Great Britain. However, with the complete unfolding of the logics of privatization typical of Modernity embodied in these enclosures, the debate about the commons faded. After many centuries of oblivion, the commons have resurfaced at the core of radical political debates in the past few years, due to the fact that we are currently facing the crisis of State sovereignty and the deployment of the logics of neoliberalism in the form of large-scale privatization supported by public authorities. In fact, as a consequence of the unprecedented strength both the private and the public spheres are employing in their ceaseless assaults on the common bounties of the world (such as forests, water, and even knowledge), a crisis occurred in the traditional radical-left and Socialist critique of capitalism, which was founded upon the belief that strengthening the State could solve the malfunctionings of the private sphere. Current critics of capitalism have realized that the State has gradually been losing its independence under the deployment of globalizing processes and has, in fact, been playing a leading role in the development of capitalism as the very supporter of privatising processes. For these reasons, today's scholars have invoked the notion of common property as a critical tool able to convey the necessity of creating a new space of politics beyond both the private and the public spheres.

Recent claims for the commons take on two main forms, according to the ways in which the concept of common property is understood and the different entities referred to when the term commonality is used. The first version-exemplified by Commons. A Manifesto by Ugo Mattei and by The Magna Carta Manifesto. Liberties and Commons for All by Peter Linebaugh-considers the commons as material and tangible wealth, and sees Nature as their origin. Through this conceptualization, these scholars rehabilitate the Diggers' notion of the commons as natural bounties produced by the Earth, as lands to till, water to drink, wood to carve, and fruits to gather. The second version, exemplified by Commonwealth by Antonio Negri and Michael Hardt, does not focus only on Nature, but rather on labouring society as the location where common property is created: production processes are, for these scholars, the source of a wealth that, having been produced in common, should therefore be enjoyed in common. Their lexical shifting from "commons" to "commonwealth" not only implies a much more abstract and dematerialized concept of common property than the one taken into consideration by the first version, but also conveys a total refusal of the logic of property implicit in the discourses about "goods" and their commitment to a scheme of reorganization of society and production that emerges as the way of reimagining Communism today. ${ }^{1}$

In spite of their differences, these two main conceptions of common property are searching for a common ground of discussion and political action, both on a theoretical and on a practical level. From this perspective, it is significant that on the occasion of the first International Festival of the Commons in Italy (Chieri, July $9^{\text {th }}-12^{\text {th }} 2015$ ), organizer Ugo Mattei invited Antonio Negri, among other scholars and intellectuals. The reason for this must be found in what these two conceptions share : the outline of a third sphere of politics, that of common property, able to force us to overcome the binary rhetoric of private/public and to go beyond the inconsistencies of both the 
market and the State. For the first version, by virtue of them being vital and basic sources of human subsistance, the commons must be based upon a collective and open access incompatible with both private and public property. Private property is, in fact, inconsistent with the commons since it is a "depriving power" (Mattei 2014, x), which contains the dispossession upon which it is founded in its own etymology (from the Latin verb privo, arre, which means "to bereave"). Moreover, if applied to the commons, private property would imply commodification. However, the commons are, in their essence, unavailable to become commodities : natural wealth, being unique, unable to be reproduced, and having to give sustenance not just to the current but also to future generations, must not be consumed, but mantained undamaged and intact. At the same time, the commons are inconsistent with public property since, for their collective enjoyment, they reject any public authority's attempt to control and govern them. The commons can only imply management from below which acknowledges no other sovereignty but the sovereignty of those who take part in their direct and collective use.

Also for the second version, the concept of common property rejects the notion of both the private and the public spheres, since both the capitalists and the State represent dangerous agents who hinder the appropriation of wealth on behalf of those who produced it. For these thinkers, the commonwealth should be the form in which the wealth is produced, appropriated, and enjoyed during and after production processes. While both these versions see labour itself as a piece of the commons, the first focuses on the material reality of producing in free and dignified conditions (Mattei 2011, 53-54), and the second stresses the urgency of reappropriating the wealth produced, proposing among other things the institution of an unconditional basic income as the means for carrying out this reappropriation and for enjoying the fruits of labor in common. This basic income would be an individual and continuous income thought as an alternative to the Welfare State as a set of social services granted by the public sphere and liable to its fiscal crisis ; in this way, it would be a means of dismantling the civilization of work and its basic logic, that sees wages as a necessary condition for accessing the rights of full citizenship (Fumagalli, Vercellone). These scholars have also theorized the notion of intellectual commonwealth : according to them, knowledge has an intrinsic relational nature since no individual can generate new ideas without relying on the basis of common ideas and on intellectual communication with others (Hardt \& Negri, 303-04). The reappropriation of the commonwealth, for these thinkers and activists, cannot be carried out by either some individuals or "the people" as a homogeneous body of men confined by national boundaries, but by a multiethnic and diversified "multitude," which is the maker of the commonwealth and can be defined as "the name of the poor" (Hardt \& Negri, 39). From this perspective, the multitude is not to be understood as the vast mass of the poor, but as all those gathered to form a political body regardless of their rank or property; it refers to a manifold and plural group which, as property is irrelevant to qualify it, stands opposite to the State defined by private property rights. This multitude constitutes a whole insofar as each member is subject to the same exploitation; nonetheless, this very exploitation does not produce uniform subjectivities, but multifarious ones. Even if it is the residual entity left after the violent appropriation historically conduced by property owners, the multitude is able to rise as a force of resistance recognizing itself as excluded from wealth but included and exploited in production (Hardt \& Negri, 52-53). 
6 In the following pages, I retrace the genealogy of this current debate by analyzing Thomas Spence's conception of common property. Spence emerges as a central figure in this genealogical reconstruction since he was able not only to anticipate the main issues at stake in today's debate, but also to offer theoretical tools to overcome some of the limitations of this debate, insofar as he considered common property a comprehensive concept which could affect every aspect of reality-both Nature and production. He raised his views of the commons during the second half of the $18^{\text {th }}$ century, when the enclosures of land started being carried out by the State (Parliament passed the first Inclosure Act when Spence was twenty-three years old) and the critique of capitalism started taking the form of a proto-Socialist apology of the State and of nationalization processes. However, in his critique of private property, Spence did not emerge as an advocate of the State but, on the contrary, as the champion of common property against both the pretenses of the capitalists and the impositions of the public sphere. It is significant that his conceptualization anticipated the main issues of today's debate, which developed as a result of the crisis of the patterns of nationalization that has occurred over the past decades. After the publication of his Lecture by Henry Hyndman in 1882, it is not surprising that the current rediscovery of Spence's thought occurred, after a century of neglect, along with the beginning of the massive process of privatization in the 1980s : in fact, the main contemporary editions of his writings (by Dickinson and Gallop, both in 1982) were published in the early years of Thatcher's premiership, as if Spence's thought was restored to curb neoliberal privatization.

7 Retracing the genealogy of the current debate on common property through the analysis of Spence's thought does not mean that this rereading of Spence makes sense only in relation to current conditions : instead, it derives its significance from the analysis of capitalist developments at Spence's times. According to Spence's thought, the commons were a specific conceptual and pratical tool of struggling against the process of privatization at the beginning of Modernity, long before their resurfacing in the last years.

\section{The eccentric Modernity of Thomas Spence}

Spence's concept of common property is rooted in an interpretation of politics which can be defined as eccentric since it revolves both within and without mainstream modern political thought. The term "eccentric" is inspired by E. P. Thompson : in The Making of the English Working Class, he wrote that "it is easy to see Spence...as little more than a crank" (Thompson, 161), i.e., as a marginal and anachronistic figure. Here, Spence's eccentricity has a completely different meaning: it underlines his ability to be, at the same time, a thinker who shared some of the main conceptions of modern political thought, a critic of capitalist Modernity, a theorist of an alternative conception of Modernity, and a forerunner who disclosed some of the issues that characterize current political debate. In this way, if one looks at Modernity, at its official discourse and at modern power relations as a closed and centripetal whole, Spence can be seen as a vector of decentralization, willing to carry out a struggle from within these relations in order to overcome and break the limits they set. In fact, his thought, after having developed within Modernity, breaks the boundaries of fixed modern thought in order to expand its meaning. 
Spence's notion of common property is the main feature of this eccentric positioning within Modernity. It is also the main constitutive element of his Plan, i.e., his political proposal to abolish private property in the land and to replace it with common management of the soil, by superseding the State apparatus with a decentralized parish system. ${ }^{2}$ The abolition of a centralized State brings out Spence's perspective that to view land as common property cannot be equated with nationalizing it. Spence's eccentric position within modern political thought, suspended between early modern claims and post-modern developments, can be analysed in light of his concept of land, which is also essential in order to understand his notion of common property. Spence's starting point are the cries, raised in the $17^{\text {th }}$ century by the Diggers, about Psalm 115 : 16 : "The heaven, even the heavens, are the Lord's ; but the earth, hath He given to the children of men". The Diggers claimed their "earth" not only in words, but also through a radical act of reappropriation : on the first Sunday of April 1649, ignoring the prescribed day of rest, they started digging the land of St. George's Hill. Their collective tillage of the soil conveyed a conception of the land as a set of material and natural commons of which nobody could be legitimately dispossessed, and which necessarily implied open, free, and collective enjoyment. In The True Levellers Standard Advanced (1649), their spokesman Gerrard Winstanley confirmed this interpretation of the land as a natural heritage : "In the beginning of Time, the great Creator Reason, made the Earth to be a Common Treasury, to preserve Beasts, Birds, Fishes, and Man" (Winstanley).

10 However, in Spence's writings, "land" not only refers to the soil and its agricultural products, but also represents the "means of industry" (Spence, ed. Gallop, 82), i.e., the springboard for new forms of accumulation typical of the second half of the $18^{\text {th }}$ century. In fact, Spence's "land" includes both natural areas and all locations of human activity, linking together under one single label both the commons and the commonwealth, both Nature's and man's production. In light of this broad definition of "land" as both a natural resource and a location of human work, Spence writes :

All things which cannot be divided justly among a number of proprietors can be enjoyed with the nicest exactness in partnership. As for instance, shipping, collieries, mines, and many other great concerns (Spence, ed. Dickinson, 119).

11 Spence is therefore convinced that it is necessary to enjoy land in common, whether it is used for primary subsistence or permanent production of wealth. In this way, his thought does not confine the concept of land to the old claims of the Diggers, but confers to it a new meaning, characteristic of the transition to the industrial age.

\section{The Plan as the common property of the commons}

Modernity emerged as the epoch of large-scale privatization, and Rationalistic thought promoted a way of conceiving of reality as founded upon the distinction between the private and the public spheres. Official political discourse presented private property as the only property regime suitable for civilized mankind, and, from this perspective, the commons were seen as the residual trace of the pre-modern world, the res nullius that needed to be overcome (i.e., privatized) in the name of progress. Spence is deeply aware of Modernity as an overarching process of privatization of common property: talking about the Recabites in Biblical times, he writes: "In those days... it seems 
engrossing of land was not arrived at the sublime perfection it has attained to in modern days" (Spence, ed. Gallop, 164-65).

The last ones to give rise to a powerful controversy on the commons before the enclosures reached that "sublime perfection" were the radicals of the English Revolution. Spence takes on their point of view-one typical of $17^{\text {th }}$ century men-when he writes :

Our rich neighbours took it [the land] into their heads to inclose our common. Then it was that you and I, and many more poor people found a great alteration. We could neither keep cow, nor sheep, nor geese as before. Every thing now depended on the ready penny (Spence, ed. Gallop, 100-01).

What Spence is describing here is what happened in England at the dawn of Modernity: the beginning of capitalistic accumulation (the "ready penny") through privatization of land and the end of the Ancien régime productive system founded upon the commons. One of the first works written at the very dawn of the process of enclosure in the $16^{\text {th }}$ century was Utopia (1516) by Thomas More. More based much of his criticism on the enclosures of land carried out by the Church in order to breed cattle and make profits, and this is the reason why Spence considered Utopia as foundational for his critique of privatization, praising More's work for being "vastly opposite to the British system" (Spence, ed. Dickinson, 16). This process marked the birth of agrarian capitalism, the precondition of the Industrial Revolution, and corresponds to what in 1867 Marx called "primitive accumulation of capital" (Marx, 713), i.e., the process which created, in the "prehistory" of capital, the foundation of the capitalistic relationship separating the labourers from the ownership of the conditions of labour. Marx considers the beginning of this process to be the expropriation of rural labourers and their expulsion from the land, thanks to draconian legislation and the violence practiced by the State apparatus. Anticipating Marx, Spence considers violence and coercion necessary to carry out this process and clearly sees the alliance between the landlords' private interests and the State's authority in the operation of privatization. Moreover, he sees primitive accumulation not only as a process of concentration and expulsion, but also as an expropriation-a primitive expropriation. In fact, Spence foresees capitalism as an incessant extraction and bereavement of value. From this perspective, embedded in his argument is the conception of capitalism as "accumulation by dispossession," theorized by David Harvey (Harvey, 63), who has recently defined both the modality of this accumulation-violence and predation-and its outcome-dispossession. Spence anticipates this very conception, catching a glimpse of capitalism as functioning to the detriment of both natural commons and human labour : to him, the extraction of value from natural commons is the precondition of the extraction of value from the wealth produced during production processes. According to Spence, the landlords had at first "deprived the mothers of nature's gifts," and secondly "pocketed the money" (Spence, ed. Gallop, 116), thus initiating a process of expropriation and accumulation which started on the land and came to affect society. Anticipating Harvey's and Silvia Federici's interpretation of primitive accumulation (Federici, 12), Spence thinks that violence and coercion do not characterize only the primitive period of capitalistic accumulation (as Marx states), but that they are actually a permanent aspect of it. In fact, "What was originally obtained by the Sword, they determine to detain by the Sword" (Spence, ed. Gallop, 92). The perpetuation of this primitive violence was once and for all formalized and made official through the institution of the State, which subjected the labourers to a harsh 
fiscal and penal system : "Remember Richmond's power ; To bind you neck and heels in cord, Bastille you in the Tower" (Spence, ed. Dickinson, 125).

It is within this critique of "primitive accumulation" that Spence's concept of common property emerges. As in current debates, the commons are outlined at first through the definition of what they are not. In fact, the commons are inconsistent with the two modern property regimes par excellence, the private and the public; this inconsistency emerges clearly from Spence's writings through a precise critique of both private property and the State. Spence sees private property as a pretense founded upon robbery and on the exclusion of others who are prevented from experiencing the same enjoyment. From this perspective, he states that landlords are but "public Robbers" (Spence, ed. Gallop, 92), since their individualistic and self-serving plunder of land is supported by public authority. Claiming private property on the commons is illegitimate since it means claiming as private property all the individuals who live on those lands :

Not an inch of land, water, rock, or heath, but was claimed by one or other of these lords; so that all things, men as well as other creatures, who lived, where obliged to owe their lives to some or other's property, consequently they too were claimed (Spence, eds. Armstrong \& Bonnett, 8).

In this way, Spence's notion of privatization anticipates not only Mattei's "depriving power," but also what Linebaugh has recently called "excommunication" (Linebaugh, 2008,271 ), i.e., the process of exclusion and estrangement from the commons that the institution of private property entails. In this regard, Spence often underlines the status of "strangers" (Spence, ed. Gallop, 108) to which the former commoners were reduced : since the State was the apparatus aimed at the protection of property rights and the commoners had been deprived of the only form of property they owned, they were de facto expelled from the right of citizenship. For Spence, the illegitimacy of land being considered private property lies also in the commodification that every privatization implies : since it coincides with the one market/State, the private/public distinction results in the establishment of private property that automatically turns the goods held as private possessions into marketable goods, i.e., commodities. But the commons are, for Spence, intrinsically unavailable to become commodities : for him, every kind of exchange which trades in vital goods delegitimizes the market and opens up an unscrupulous commodification of the world, which is profitable only to the greedy desires of landlords. Spence realizes the extent to which the phrase "free trade" conveys the existence of a market emancipated from any moral obligation :

Must nothing be held sacred from Commerce? No! It seems not. But in order to give free Scope to the Speculations of these People of Property all Bounds must be thrown down and Every Thing must be vendable...In this manner Venality and the Cursed Spirit of Traffic pervades Everything (Spence, ed. Gallop, 130). Spence's critique of private property is foundational to his critique of the State. For Spence, the central power is no less responsible for continuous assaults against the commons than the landlords, whose illegitimate claims are always supported and justified by public authority. Spence clearly sees the alliance between the public and the private spheres: the State is, for him, instrumental in submitting one part of society to the other, since it is used as a tool of power by the landlords on the labourers. Spence was deeply aware of the political consequences derived from the conceiving of the State as a legal and institutional apparatus built to defend privatization and the destruction of the commons : 
The property is the nation...Which is saying that property is the public, and that the public is property. And all things are ordered accordingly. For the laws are made by property, and for property (Spence, ed. Dickinson, 98). property is common property. Let's first examine private property. To Spence, the commons are intrinsically anti-individualistic and inconsistent with any kind of property which involves exclusion: "[The land], I do not give it to one, or two, or a select few, but to you all...as a COMMON PROPERTY. You shall all be EQUAL OWNERS" (Spence, ed. Gallop, 76-77). The commons' inconsistency with private ownership is also due to their unavailability to become a commodity. For Spence, a piece of the commons would become a commodity only if reduced to an abstract object, separate from the subjects who live on it; but the commons, if reduced to this abstraction, would lose their very essence. Indeed, Spence considers the commons as the absolute opposite of commodities, since the commons are founded upon intrinsically anti-economic considerations. Their exchange value is insignificant compared to their use value ; in other words, their exchange value has to be minimized in order to have their use value safeguarded. In light of this, we can grasp the meaning of Spence's insistence on the impossibility of selling and buying land after his Plan was implemented, to the extent that he completely rejects the institution of small landholdings (Spence, ed. Gallop, 142), preventing every business of profit and gain and every matter of money from affecting the commons.

20 Now let's examine State property. The commons do not need any State supervision to be collectively enjoyed and they are beyond the attempt of any authority to control and govern them from above. Instead, they require management from below, open to everyone on the basis of horizontal relations. The independence of the commons from the State means, for Spence, independence from the limited temporality that every human institution implies : more than legal rights, the commons are perpetuities. This is why Spence always refers to timeless essences like God and Nature in his writings : they mirror this very necessity of rooting the idea of the commons not in human history (or, even worse, in the history of the State), but in human beings.

21 The incompatibility of the commons with both private and public property also derives from their relational and collective nature : in fact, in a common property regime, the interests of each individual are satisfied only with the interests of others, and not against them (as happens with private property) or regardless of them (as happens with public property). It is precisely by virtue of their relational nature that knowledge and inventions are considered, by Spence, as a piece of the commons. Intellectual property as a part of the commons is a feature of surprising originality and foresight in Spence's thought. Moreover, it emerges as further proof of the fact that the notion of common property pervades every aspect of Spence's meditation, affecting not only material, but also immaterial, wealth. In A Further Account of Spensonia he writes :

If any man possess an invention, or secret, in medicine, or other science, or art, or importance to mankind, the state does not first tax the possessor by selling him a patent...No : the parliament is obliged to purchase the secret, and publish it (Spence, ed. Gallop, 90). 
Spence's call for the abolition of patents for those inventions that represent "blessings" (Spence, ed. Gallop, 90) for humanity and for their organized propagation depicts him as a forerunner of the current notion of "copy-left," i.e., the idea of the breaking down of the barriers of the right of intellectual property and the evasion from its strict regulations. For Spence, the patent is a symbol of private knowledge (and, as such it is, used to deprive others of knowledge itself). Therefore, it is necessary to escape from the regimentation of patents in the name of common interest. For Spence, knowledge is intrinsically relational since confrontation among individuals is indispensable to its production, whereas the privatization of information and inventions hampers their propagation and curtails general innovation.

Also Spence's reform of English pronunciation ${ }^{3}$ (the invention of the so-called "Crusonian Alphabet") can be viewed in the same perspective of common property: Spence knows that while language should be a commonwealth, since it is commonly spoken and listened to, large portions of it are subject to complex grammatical and phonetic rules that make them inaccessible to the main body of the people and that can be construed not only as privately appropriated but also as publicly imposed. This control is aimed at regulating access to the linguistic skills necessary to social and economic inclusion. Spence sees discrepancies between spelling and pronunciation as a by-product of social inequality : in this way, the alphabet emerges as a tool of command by one part of society over another. With his Crusonian reform, Spence purports to make it possible for every social group to reappropriate its own means of communication and redistribute the communicative power of language :

I cannot but think it possible such a method of spelling may take place, especially among the laborious part of the people, who generally cannot afford much time or expence in the educating of their children (Spence, 1775).

\section{The Plan as a reappropriation of the commonwealth}

When Spence started writing in the second half of the $18^{\text {th }}$ century, the term "commonwealth" already had a long history. According to Hobbes, the Commonwealth was the State-in its etymological sense of a fixed, steady, and motionless entity-while Harrington described the Commonwealth of Oceana (1656) as a Republic, a political form which did not imply the neutralization of the natural movement of politics represented by the State. But Spence's notion of commonwealth is of a different sort. From his perspective, it is a form not only of political organization, but also and most importantly of social organization, to be understood in its etymological sense as the wealth produced in common by society and which men must enjoy in common against any private or institutionl attempt to exercise control over it.

For Spence, this common enjoyment coincides with the reappropriation of the commonwealth. This reappropriation will take place via the system of dividends first enunciated by Spence in the ballad The Rights of Man published in 1783. Spence explains that rents would have to be paid by parish inhabitants for the tillage of the land, and after having paid all administrative expences, the remaining two-thirds of the rents would be the dividends, i. e., the shares that were to be redistributed quarterly and equally "among all the living souls in the parish, whether male or female; married or single; legitimate or illegitimate; from a day old to the extremest age" (Spence, ed. Gallop, 119). Since the money redistributed in the form of dividends would derive from 
the rents paid for tilling the land, and since in their turn the rents would be paid with the money earned by the work of each individual, once this money was shared as dividends, it would imply a redistribution of the wealth of society among those who produced it. Spence writes in The End of Oppression:

The Landed Interest...is literally paid for nothing but to create Masters. - I say only think of all this Money, circulating among the People, and there promoting Industry and Happiness" (Spence, ed. Gallop, 96).

The "creation of Masters" mentioned here can be overcome by "circulating" in society the wealth that until then was subdued by a logic of private expropriation :

The perpetual influx of wealth by their Rents without toil or study, leaves them at full Liberty and Leisure to plot, and supplies them also with the means of fighting successfully against the interests of the working part of the Community, and turn their labours to their own advantage (Spence, ed. Gallop, 93).

Therefore, what Spence demands is an inversion in the direction of this "influx of wealth" from exploiters to producers; only thus will the landlords' revenue change from a means of dominion over society into an instrument of emancipation of society from dominion. Here, Spence does not perform a critique of revenue, as any other leftwing radical would. Rather, he carries out a powerful critique of the private and individualistic appropriation of revenue : the rents paid by the tenants to the landlords are revenue, i. e., income arriving continuously and without toil or costs in landlords' pockets. The landlords, using this revenue for individual and private purposes, had historically been able to make it an instrument of social command and of illegitimate appropriation of the labourers' work. In this sense, even the redistribution of Spence's dividends would be a fulfillment of revenue. However, having been released from its former private purpose, this revenue would cease to be used as an instrument for the perpetuation of social inequality. Instead, the dividends would produce a socialization of the revenue, becoming a commonwealth and turning from a means for the few to dominate the many, into an instrument of emancipation of the many from the few. As Spence writes : "This would...be.... continual flow of permanent Wealth established by a System of Truth and Justice" (Spence, ed. Gallop, 96).

Spence's proposal of distributing dividends shows more than an element of kinship with the current movement asking for unconditional basic income. In particular, Spence seems to anticipate the most radical way of conceiving of unconditional basic income : an income independent from age, sex, employment, civil status, penal charges, and even from citizenship. While it is true that only parishioners have access to the dividends, citizenship is conceived of by Spence as an open condition, since anyone dwelling in a parish for a year automatically becomes a citizen and is as such entitled to parochial shares. However, Spence's redistribution of dividends seems closer to the logic of universal revenue than to that of universal income: his dividends would represent a "continual flow of permanent wealth" owed to everyone "without toil or study". The dividends would not depend on individual employment, since no unemployed individual would be debarred from redistribution. In this way, the system of the dividends would be what we could call unconditional basic revenue. However, with no contradiction, the dividends would also represent the necessary reimbursement owed to the working society meant as a collective body :

All riches come from society, I mean the labouring part of it. And when all these improvements return back to society, they will only return to the source from whence they came (Spence, ed. Dickinson, 120). 
In this way, having at its core dividends as a system for the reappropriation of revenue, the Plan itself would be a project of reappropriation and redistribution of the commonwealth. This reappropriation would have an intense emancipating function. In fact, Spence's main purpose appears to be the fullfilment of individual and collective freedom on the basis of equality-which is meant not as a levelling of economic conditions, but as an absence of social and political command. In this way, the dividends would have a social, rather than a merely economic function : the purpose of the Plan is not the removal of economic differences (since commonality would affect only land and not movable possessions), but rather the abolition of the negative outcomes of these very differences on freedom and equality, i.e., social inequality and political hierarchies.

\section{The agent of the reappropriation : the "swinish multitude"}

Anticipating Hardt and Negri, Spence considers the multitude as the political subject who has to become the agent of the reappropriation of the commonwealth. In fact, those to whom Spence addresses his ideas and with whom he fosters his fight are neither individuals considered singularly nor "the people" meant as a homogeneous body of subjects/citizens. On the contrary, Spence is referring to the members of the "swinish multitude" : the poor and differentiated fourth estate who fell victim to the privatization of the commons at the dawn of Modernity. Spence drew this phrase from Edmund Burke's Reflections on the French Revolution (1790). But while Burke considered the multitude with contempt, as the lowest social group threatening the stability of established order, Spence polemically recovered "swinish multitude" with a positive meaning. Spence's multitude can be compared to the image of the "Many-Headed Hydra" conceived of by Peter Linebaugh and Marcus Rediker (Linebaugh, Rediker, 2000). In fact, the Spencean multitude has a Hydra-like nature, insofar as it emerges as a radically plural and open political subject, embracing all those who, on both sides of the Atlantic, work and toil under the command of the capital and resist it with instances of emancipation in manifold and multifarious ways. Spence's multitude is multiethnic, since it includes not only British poor, but also native Americans and African slaves. Spence writes that, under the Plan, "the warlike Indians" as well as "the slaves and disenfranchised labourers of other nations would...find emancipation" (Spence, ed. Dickinson, 44). He also "beg[s] to be understood as laying down a system of government for the free-born, unshackled minds of the North American and African savages" (Spence, 1792, 1). The European, African, and American members of Spence's Atlantic "swinish multitude" share the same creative force: "The earth has been cultivated either by slaves compelled... to labour, or by the indigent" (Spence, ed. Gallop, 121-22) ; likewise, "slaves and unfortunate men have cultivated the earth...and filled it with all kinds of riches" (Spence, ed. Dickinson, 120). But they also share the same revolutionary potentiality: "As often as such periodical revolutions happened in favour of the Rights of Man, they... were procured by the irresistible importunities of the slaves and the landless men" (Spence, ed. Gallop, 69).

31 Spence's multitude is not defined by its nationality : instead, its status as a "stranger" (Spence, ed. Gallop, 108) is often stressed by Spence. From this perspective, the fact that the multitude lives in a country entirely possessed by others and must ally with 
the oppressed of other nations foreshadows the internationalist outline of Marxian proletariat. Moreover, Spence conceives of the fulfillment of his Plan on an international scale: "My plan...is as well calculated for any nation under the Heavens" (Spence, ed. Gallop, 158). Nevertheless, compared to Marx's proletariat, Spence's multitude preserves a heterogeneity and an inner diversification that wouldn't have been familiar to the Marxian conception of the working class. In fact, as if foreshadowing current debates, Spence considers the multitude as a concept able to express, at the same time, the multiple subjectivities involved in the struggle and the coordination of their common action. Spence's multitude has a collective nature (which is the precondition of its collective action) because of the common coercion it suffers. However, at the same time (being the opposite of "the people," which is a depersonalizing concept), it does not imply any nullification of the subjectivities at stake, which are anti-individualistic (since they are not defined by private property rights) but preserve an individual dimension. As the producer and the legitimate caretaker of the commonwealth, the Spencean "swinish multitude" can be described with Hardt and Negri's definition, "the name of the poor." The meaning that Spence ascribes to poverty in reference to the multitude is not obvious: the poverty of his multitude does not necessarily point out to a condition of real need, but denotes all those who gather to form a political body regardless of their possessions. Finally, in spite of its constitutive plurality, the multitude can, for Spence, organize and acquire a synchronous and revolutionary movement, managing to destroy the old system and establish a brand new political order : "For in a mass, like a flood o'er they pass, They'll sweep all their [the landlords'] greatness away" (Spence, ed. Dickinson, 128).

\section{The management of the commonwealth : the end of poverty}

The system of dividends involves, for Spence, the establishment of a decentralized administrative apparatus which emerges as an alternative form of social organization in lieu of the modern State. This apparatus is assigned to the management of society and has as its first purpose the administration of the poor. In this way, Spence's project of societal management is envisaged primarily as a fight against poverty.

33 As part of the wide debate on the Poor Laws which developed in Britain between the $18^{\text {th }}$ and $19^{\text {th }}$ centuries, Jeremy Bentham wrote the Essays Relative to the Subject of the Poor Laws (1796), where he distinguished poverty from indigence: while the poor had to work in order to survive, the paupers were either unable to survive on their meagre wages or unable to work altogether (Bentham, ed. Quinn, 3). It will be shown that Spence's redistribution of dividends would not only grant everyone enough to live on (thus putting an end to the paupers' condition), but would also remove the necessity of working in order to have access to these means (de facto eliminating the Benthamian poor as well). The overall purpose of the fight against poverty as conceived of by Spence derives from his notion of poverty itself.

In fact, in Spence's thought, poverty emerges as a political concept with a peculiar meaning : poverty is mainly a social and not an economic condition, the opposite of which is not abundance of wealth and goods, but social equality and freedom. In this way, in Spence's writings, the term "poverty" is semantically quite broad, referring not only to the paupers and the indigent, but to all those who, because of many kinds of 
dispossession, are not free to make their own decisions regarding their own existence, and are subjected to social and political command. Therefore, the poor derive their condition from the fact that they are forced and constrained in and by a system which does not allow the lower classes to control their own lives according to their will and inclinations (Spence, 1795). Since the poor, under their many guises, would be able to overcome this lower social condition by the establishment of Spence's Plan and by his redistribution of dividends, the Plan itself can be considered a system of Welfare avant la lettre, whose implementation does not depend on a centralized State, but on the local administration. From this perspective, Spence states that the redistribution of dividends, as it does not involve central power but parochial management, would imply the "very little influence" (Spence, ed. Gallop, 126) of the government : therefore, not only does the system of dividends not descend from any central government, but, for it to be effective, it is necessary to do away with government altogether.

The sharing of dividends would guarantee everyone the basic means of subsistence, thus allowing the paupers to overcome their former miserable condition. In fact, after the Plan is implemented, the situation would be incomparably improved from the one that prevailed beforehand, when shortage of economic means coincided with indigence. Moreover, if the system of dividends were established, it would emancipate the poor from poverty as a condition of deprivation that made them prey to coercion, thus ending not only indigence, but poverty itself in the broadest sense, as explained above. So, not only would beggars and starving men be granted a decent existence, but the condition of all those who were formerly not free to make decisions about their lives (for economic, social, or even intellectual reasons) would disappear. Since each individual would keep all the movable goods he or she used to own before the Plan was enforced, there would still be those who have more and those who have less; but these merely economic differences would cease to produce social and political inequality. Therefore, after implementation of the Plan, no individual would find him- or herself with no alternatives in life.

In this way, the first result of Spence's Plan is to support the paupers, who "from the vices and miseries of hopeless grovelling poverty, would at once be elevated to the virtues, consequence, and happiness of mediocrity" (Spence, ed. Dickinson, 56). After having "delivered...the Indigent from their... Misery by abolishing the Causes" (Spence, ed. Gallop, 163), the Plan would overcome the condition of exploitation and lack of independence of the poor in general. From this perspective, Spence writes that under his system, "the poor would have the advantage every way and might turn to what calling they liked without compulsion" (Spence, ed. Claeys, 320). In fact, the redistribution of dividends would also increase social mobility, by allowing each individual to improve his or her condition by his or her own exertions. In fact, with respect to the labourers, Spence states that

Such also as aspired to become masters would have an opportunity of saving money for that purpose. It would not be as now, once down and aye down. No, there would then be a possibility of rising again (Spence, ed. Dickinson, 56).

In this way, poverty in its broadest sense would be extinguished. Therefore, when in his writings, Spence mentions the poor even after the establishment of the Plan, it is clear that he means a different kind of poverty than that which existed before the Plan: while poverty before the Plan was a never-ending condition of deprivation and suffering, poverty after the Plan would no longer produce social and political hierarchies. Poverty after the Plan would coincide with a small availability of money, 
but it would never jeopardize the means of sustenance; moreover, it would be temporary, since the sharing of dividends would allow everyone to recover : "So if by Sickness or Mischance To Poverty some wane, Their Dividends of Rents will come To set them up again" (Spence, 1783, 106).

The system born from the Plan would allow everyone to achieve a virtuous "mediocrity" (Spence, ed. Gallop, 148). On the one hand, this term is reminiscent of classical mediocritas : in The Restorer of Society, Spence writes that "Mediocrity of Wealth has always been found to be the never failing source of Knowledge, Good Taste, Industry and Happiness, and of all the virtues" (Spence, ed. Gallop, 148). On the other hand, in Spence's thought "mediocrity" has a strong implication of social equality unparalleled in ancient authors. This improvement of economic conditions would be far from being, as it was for the Calvinists, a social divider, splitting the elects and the damned on the basis of their economic differences. On the contrary, Spence's system would give each and everyone a chance, thanks to the redistribution of dividends :

The houses and everything about them are so amiably neat...that they seem the habitations of rational beings; of beings worthy the approbation of the Deity, because, though as he designed them they be lords of all his works, they presume not be Lords of each other (Spence, ed. Gallop, 87).

Here, Spence is mimicking the core of Puritan ethics (economic ease as the outer sign of God's approval) in order to assert the opposite. In fact, he is saying that the real opportunity for everyone to achieve social "mediocrity" after the Plan would seem to fulfill Calvinist doctrine, making the world as if men had derived their wealth from a divine predilection. But there is nothing more remote from Spence's thought than Calvinist discourse, for the simple reason that the generalized "mediocrity" which would be achievable under Spence's system is open to everyone, while Puritanism is founded upon the co-existence of the election of the wealthy and the damnation of the poor : the two conditions implicate each other, and poverty must exist for the doctrine itself to work. Instead, Spence's "mediocrity" has to be understood as an absence of social and political hierarchies : what matters most is that men cannot be "lords of each other" any longer.

\section{Beyond the civilization of work}

The other issue around which Spence sketches out the emancipation produced by the system of dividends is labour, which is strongly connected to poverty. I have shown that, before the establishment of the Plan, labour is characterized by "accumulation by dispossession." In fact, for Spence the division of society between the rich and the poor is founded upon a dynamic relation of oppression and resistence between "the spoilers and the spoiled" (Spence, ed. Gallop, 116), which manifests itself in labour relations. Therefore, work as an abstract concept typical of Liberal discourse is turned by Spence into the concrete toil of the labouring classes, emerging as a dimension of encounter and conflict, a real battlefield where the struggle for the appropriation of wealth between legitimate and illegitimate owners occurs.

41 Spence indicts the landlords (and the organization of work they established) not only for dispossessing the labouring class, but also for condemning them to restless work that deprives them of free time. Therefore, the labourers are doubly dispossessed, both of wealth and of time. Time is, for Spence, a matter of freedom : free time, being the 
time of individual regeneration, represents a dimension of freedom that every labourer is entitled to. From this perspective, in The Restorer of Society, Spence shows the appropriation of wealth and time by the landlords as two sides of the same strategy of dispossession :

When the People began to talk of Keeping Holiday...So instead of allowing them Holidays he increased their Tasks...Our Taskmasters because we talk of Liberty take care to manage matters so that we should be closely employed and instead of working only six Days a Week we are obliged to work at the rate of Eight or Nine, and yet can hardly subsist (Spence, ed. Gallop, 132).

In this way, the institution of dividends would represent the reappropriation of both wealth and time. So not only would Spence's Plan emancipate labourers from exploitation and dispossession, but it would also free man from any control which the State and the group of capitalists had formerly tried to impose on him by coercion to work. On the one hand, after the Plan, the working conditions would be overhauled, since all forced and exhausting labour would cease. This would produce an emancipation of work from the conditions that had formerly characterized it : after the Plan, "industry will be relieved of the almost insurmountable fetters of the present hour" (Spence, ed. Dickinson, 20). However, on the other hand, the Plan would also produce an emancipation of man from work: under the new system, work would no longer be a compulsion. In fact, even though Spence writes that "[there] would be no other than to live as sober, industrious citizens, mantained by their own industry" (Spence, ed. Gallop, 73), he does not share the ethics of indefatigable work: his statement addresses all those who never were sober and industrious, i. e., the landlords. Instead, he denounces the hypocrisy of Puritan rethoric of restless labour, unmasking landlords' self-serving purposes: 'You may then guess the Cause why all this outcry is about work, for well they know that some People must labour to uphold such a shameful mass of Extravagance and Idleness" (Spence, ed. Gallop, 133).

The Plan would provide the genuine possibility of free individual choice as to the amount of time one wanted to work, and would produce a new system different from the constant requirement of ceaseless work, to which the birth of capitalism had doomed the lower classes. In fact, starting from the "primitive" expulsion of rural labourers from the lands in the $16^{\text {th }}$ century, a mutation and a deterioration in the condition of the poor occurred : former commoners were made "proletarians" who, being dispossessed of the commons, by then did not own anything but their offspring and the product of their toil (Linebaugh, 2008, 65). Under Spence's Plan, the conditions of the poor would be very different. Everyone would be responsible for his or her own earnings :

Where would be the great harm if some Men should but perform half their ordinary work if they be content with half wages or half gains? ...There would be Enough of Work done for the happiness of Society though Men should not be always toiling like Slaves (Spence, ed. Gallop, 132).

Under the new parochial system, one would work to live, not live to work. In fact, everyone would work (rather, every social group would work), but everyone would do it freely, and this absence of coercion would allow every man or woman to decide not only for how long to work, but also whether he or she wants or needs to work. The only social duty imposed by the parish administration would be the payment of the rent to till the land : anyone who would not have to work to pay it (as movable goods would not be held in common), would be free not to work at all. Work would no longer 
represent an obligation; in this way, the dividends, overcoming work as a necessary condition for an income, would abolish the necessity of work itself. From this perspective, as I have shown, the system of dividends would produce a transition from a civilization of wages to a civilization of revenue : while salary is intrinsically linked to the work performed in order to earn it, revenue is independent from work. In this way, income would cease to coincide with wages, which everyone had previously had to earn with incessant toil, and would become revenue, a right simply derived from citizenship. In this way, while wages were formerly a necessary condition to access citizenship, after the Plan was implemented, citizenship itself would give access to an income-or, even better, to a revenue.

Therefore, after the Plan, the emancipation of man from work would imply an increase in free time, as a creative and autonomous reappropriation of one's individual existence. From this perspective, consider that while the French Jacobins in the French Revolutionary Calendar (1792) had lengthened the week into "decade" (ten-day week) in order to have nine days of work against just one of leisure, Spence in The Constitution of Spensonia shortened the week to five days (Spence, ed. Gallop, 184), in order to increase man's free time, thus repudiating the Jacobins' commitment to work. The importance of rest is stressed in The Constitution of a Perfect Commonwealth, where Spence writes that Spensonians (the citizens of Spensonia, Spence's utopian island) should be granted the right to "be hospitable to one another, to entertain a friend, to relax a little now and then from incessant labour" (Spence, ed. Dickinson, 56) : in this system, the more free time would also contribute to the renovation of social relations.

In this way, earlier dispossession would be turned into reappropriation, and earlier exploitation into cooperation. Spence, according to the logic of common property, reconsiders not only the enjoyment of the wealth produced, but also its very production : he outlines a cooperation which has to be understood as work performed in common, but without any implication of collectivism, which would bring Spence's discourse back to the logic of the centralized State. In fact, in one of his letters to economist Charles Hall, Spence criticizes Hall's proposal of social trasformation since it "makes every kind of Property the Property of the Nation," thus producing nationalization, and obliges the labourers to "work under Gang Masters" (Spence, ed. Claeys, 320), thus producing collectivism. Spence's Plan, on the contrary, would at the same time liberate work and free men from work-a freedom based upon variety and difference, and not upon the homogeneity collectivism implies.

Therefore, Spence's Plan and his concept of common property represent a new order which goes beyond the civilization of work, appearing much earlier than the development of advanced industrial society and the deployment of the very logics of the civilization of work. The Plan itself emerges as a pattern foreshadowing an alternative idea of society, where wages would cease to represent the tool of command of the few over the many, and where everyone, enjoying the fruits of his or her own labour, would no longer be employed by a master but would work for him- or herself :

There would be no occasion for Gang-masters...to make People till their land properly...In so prosperous a State as this, there would be few Labourers or Journeyman in any Line of Business. It would be little Farmers and little Mastermen...And where Prodigality or Mischance did not prevent those hiring themselves might soon be above such Necessity (Spence, ed. Claeys, 320). proposing today, at the end of Modernity : a "transformation of labour through labour" 
where work itself could become "the foundation not of the establishment of private property but of its abolition," in light of the deployment of new "equilibriums able to secure the production by man for man" (Negri).

\section{BIBLIOGRAPHY}

Bentham, Jeremy. The Collected Works of Jeremy Bentham : Writings on the Poor Laws, ed. by Michael Quinn. Oxford : Clarendon Press, 2001.

Bonnett, Alastair, Armstrong, Keith (eds). Thomas Spence. The Poor Man's Revolutionary. London : Breviary Stuff Publications, 2014 (contains : Spence, Property in Land Every One's Right, 7-11).

Burke, Edmund. Reflections on the French Revolution. 1790. London : J. M. Dent \& Sons, 1951.

Claeys, Gregory (ed.). “Four Letters Between Thomas Spence and Charles Hall.” Notes and Queries $28: 4$ (1981) : 317-321.

Dardot, Pierre, Laval, Christian. Commun. Essai sur la révolution au XXI ${ }^{e}$ siècle. La Découverte : Paris, 2014.

Federici, Silvia. Caliban and the Witch. Women, the Body and Primitive Accumulation. Autonomedia : New York, 2004.

“French Revolutionary Calendar." Projekte auf Ortelius.de (1 Sept 2007). 21 June 2015.

$<$ http://www.ortelius.de/kalender/fr_en.php>.

Fumagalli, Andrea, Vercellone, Carlo. "Reddito di base incondizionato come reddito primario." Effimera.org (17 June 2015). 21 June 2015.

<http://quaderni.sanprecario.info/2013/10/reddito-di-base-incondizionato-come-redditoprimario-di-andrea-fumagalli-e-carlo-vercellone>.

Hardt, Michael, Negri, Antonio. Commonwealth. Cambridge (MA) : The Belknap Press of Harvard University Press, 2009.

Harvey, David. “The 'new' Imperialism : Accumulation by Dispossession.” Socialist Register 40 (2004) : 63-87.

Linebaugh, Peter. The Magna Carta Manifesto. Liberties and Commons for All. Berkeley : University of California Press, 2008.

---, Stop, Thief! The Commons, Enclosures, and Resistance. Oakland : PM Press, 2014.

---, Rediker, Marcus. The Many-Headed Hydra. Sailors, Slaves, Commoners, and the Hidden History of the Revolutionary Atlantic. Boston : Beacon Press, 2000.

Locke, John. Two Treatises of Government, ed. by Peter Laslett. Cambridge : Cambridge University Press, 1988.

Marx, Karl. Capital : A Critique of Political Economy. vol. I. 1867. New York : International Publishers, 1967.

Mattei, Ugo. Beni Comuni. Un Manifesto. Bari : Laterza, 2011. 
---. “Senza proprietà non c’è libertà.” Falso ! Bari : Laterza, 2014.

Negri, Antonio. “Lavoro e proprietà a fronte del comune.” EuroNomade (July 2015). 23 July 2015. <http://www.euronomade.info/?p=857>.

"Psalms 115 : 16." The Official King James Bible Online (July 2015). 14 July 2015.

<http://www.kingjamesbibleonline.org/Psalms-115-16/>.

Spence, Thomas. The Grand Repository of the English Language. Newcastle-upon-Tyne : Printed by T. Saint, 1775 (London, The British Library, General Reference Collection X.989/4357).

---, “The Rights of Man : First Published in the Year 1783." Eighteenth Century Collections Online. Text Creation Partnership (24 Dec 2014). 21 June 2015.

<http://quod.lib.umich.edu/e/ecco/004899815.0001.000/1:1?rgn=div1; view=fulltext>.

---, Preface to The Rights of Man. London : 1792 (London, The National Archives, T.S., 24/03/15).

---, The Contrast. London : 1795 ? (London, The British Library, General Reference Collection Cup.

21g.32./5).

---, The Political Works of Thomas Spence, ed. by Harry Dickinson. Newcastle-upon-Tyne : Avero, 1982 (contains : Spence, The Case of Thomas Spence, 15-21; The Reign of Felicity, 41-44; The Constitution of a Perfect Commonwealth, 54-69 ; The Important Trial of Thomas Spence, 92-103 ; A Dream, 118-20 ; Edmund Burke's Address to the Swinish Multitude, 124-26; The Downfall of Feudal Tiranny, 128-29).

---, Pig's Meat. Selected Writing of Thomas Spence. Radical and Pioneer Land Reformer, ed. by Geoff Gallop. Nottingham : Spokesman, 1982 (contains : Spence, An Interesting Conversation, between a Gentleman and the Author, on the Subject of the foregoing Lecture, 67-75 ; The Marine Republic, 76-79 ; A Further Account of Spensonia, 80-90; The End of Oppression, 91-97; A Letter from Ralph Hodge to his Cousin Thomas Bull, 100-04 ; The Meridian Sun of Liberty, 107-10 ; The Rights of Infants, 111-26 ; The Restorer of Society to its Natural State, 127-65 ; The Constitution of Spensonia, 166-85).

Thompson, Edward P. The Making of the English Working Class. New York : Vintage Books, 1963.

Winstanley, Gerrard. "The True Levellers Standard Advanced : Or, the State of Community Opened, and Presented to the Sons of Man." Marxists Internet Archive (July 2015). 14 July 2015. <https://www.marxists.org/reference/archive/winstanley/1649/levellers-standard.htm>.

\section{NOTES}

1. Worthy of mention although slightly different from Hardt and Negri's conception is the idea of common property recently expressed in the massive work by Pierre Dardot and Christian Laval: Commun. Essai sur la révolution au XXIe siècle. Similar to the authors of Commonwealth, Dardot and Laval believe that commun is a "political principle," which originates only from a common action (Dardot, Laval, 15). However, different from Hardt and Negri, they stress the political and juridical features of commun to the detriment of the material, social, economic, and productive dimension, which is at the core of Hardt and Negri's analysis.

2. Spence's Plan was first presented at the Newcastle Philosophical Society in 1775 in a lecture titled Property in Land Every One's Right. Its main contents remained basically unchanged throughout the many pamphlets and poems, which Spence wrote in the following forty years. However, the term "Plan" did not appear till 1782, in A Supplement to the History of Robinson Crusoe, where Spence started naming it so, replacing the terms "prospect" and "method" appeared in his first lecture (Spence, eds. Armstrong \& Bonnett, 9-11). 
3. See Joan Beal's article in this collection for more information on that topic.

\section{ABSTRACTS}

The purpose of this article is to show the concept of common property of Thomas Spence $(1750-1814)$ as a genealogy of the current political debate about the commons. This debate is characterized by two main ways of conceiving of common property: one that considers the commons as a material heritage produced by Nature, and one that focuses on labour and proposes the concept of commonwealth for the wealth produced during production processes. Spence's Plan reconciles the differences between these two versions of common property: in fact, being a project for the reappropriation of both the commons and the commonwealth, the Plan offers the conceptual tools to help overcome the limitations of the current debate.

L'intention de cet article est de présenter le concept de propriété commune de Thomas Spence (1750-1814) comme une généalogie du débat politique actuel à propos des biens communs. Ce débat est caractérisé par deux manières différentes de concevoir la propriété commune: la première qui considère les biens communs comme patrimoine matériel produit par la nature, et la deuxième qui se concentre sur le travail et propose le concept de commun pour signifier la richesse produite au cours de procédés de production. Le Plan de Spence concilie les différences entre ces deux versions de la propriété commune : en effet, étant un projet de réappropriation aussi bien des commons que du commonwealth, le Plan offre les outils conceptuels pour dépasser les limites du débat contemporain.

\section{INDEX}

Keywords: property, commons, modernity, multitude, poverty, freedom

Mots-clés: propriété, biens communs, modernité, multitude, pauvreté, liberté

\section{AUTHORS}

\section{MATILDE CAZZOLA}

PhD student

University of Bologna

matilde.cazzola2@unibo.it 